\title{
The Masculinization and Militarization of the
} Female Sexualized Body in Zoé Valdés's Yocandra in the Paradise of $N A D A$

\author{
Mary Louisa Cappelli
}

\author{
MFA, JD, PhD, Nevada State College, Nevada
}

\begin{abstract}
Is this a garden or a cemetery? I want a garden. I need a garden. How proud I am to be Cuban! How terrified I am to be Cuban!" declares Yocandra in Zoé Valdés's Yocandra in the Paradise of NADA. In this essay, I interrogate the revolutionary contradictions inscribed on female sexualized bodies showing how women's histories are registered in their scars, each scar representing a historical marker in the body's memory of lived experience. Moreover, I examine how Valdés's narrative fiction reveals how subjugation and exploitation often materialize as sexualized and politicized wounds. The female sexualized and eroticized body works as an allegorical transcript for the toxic masculinization and militarization of the Cuban Revolution.
\end{abstract}

Keywords-Cuba; Cuban Revolution; Fidel Castro; Zoé Valdés; sexual violence; Yocandra in the Paradise of NADA; George Bataille; eroticism; body politic.

\section{INTRODUCTION}

According to George Bataille (1991) females in eroticism are victims and the male is a "sacrificer," "during the consummation" in which he loses himself "in the continuity established by the first destructive act" (p. 42). For Bataille both sex and death are excessive, and must be measured. The fear of death and lack of control of individual destiny are the critical moments that taboo and transgression occur. Women are placed within this sexual conundrum to flatter patriarchal "festivity," and "champagne" and to benefit male pleasure and enjoyment (Bataille, 1991, p. 42.) Informed by Bataille's dialect of taboo and transgression, I explore the ways in which the extreme and transgressive sexual behaviors of Valdés's characters in Yocandra in the Paradise of Nada are metaphorical sites of struggle "between the margins and the center" of oppression, struggle, and "competing ideologies" (Conboy, Medina, \& Stanbury, 1997, p.7). Valdés's female bodies attempt to break through the limits of personal and political consciousness by subverting and shattering patriarchal revolutionary icons and discourse. Sexual orgasm ultimately leads to crisis and liberation. For as Valdés herself observes, "In Cuba, the sexual act, the moment of orgasm, is the only time that one is truly free" (Rohter, 1999). Valdés demonstrates how the complicated socio-economic, cultural, political history of the revolution is transcribed on women's sexual bodies. She also reveals the reality of Cuba's Special Period-one that Valdés personally endured.

Uno de los elementos más interesantes acerca de La nada cotidiana . . . es este deseo de dar un testimonio, político, ideológico, histórico, acerca de esta realidad que has vivido. Hay una necesidad de hacer no sólo literatura sino de nombrar la realidad tal como la ve no un personaje, sino tú misma. (Santí, 2002, p. 407). ${ }^{1}$

In this sense, the female body itself becomes a product of its revolutionary culture, an allegory of lived experience of the Cuban body politic (Grosz, 1994, p. 23.) ${ }^{2}$

\section{MORIR POR LA PATRIA ES VIVIR}

In "Morir por la Patria es Vivir," Valdés (1997) begins: "She comes from an island that had wanted to build paradise" (1). Immediately, the narrator is cast into purgatory caught between the paradoxical nature of life and death, living and dying on the borderlands of existence in which "every part of the body learned to resist, as "sacrifice was the order of the day, as was nada, nothingness" (Valdés, p. 2). The motif of nada and waiting in the spaces of nothingness permeates the discourse of mystery and shadow in which the narrator is told her "soul is too 
innocent to deserve hell, and just evil enough not to deserve paradise" (p. 5). In the purgatory of being and nonbeing where "to die and to live" are the same verb as to laugh" (p. 2 ), the narrator realizes that "she has never been "she who decided for herself" (p. 5). In this exilic outpost, there are no real spaces for women. Whether on or off the Cuban Island, women are not included in the "national teleology" (Fuentes, 2002, p. 31). And so, Yocandra remains in the nada, the void, the sacrificial limbo caught between the racialized, gender, and geographic exterior that shapes her psychic interior (Fuentes, 2002, p. 151). Yocandra's body reflects this dialectics of exile-“change," "process," "flux," "conflict" and oppositions" all which contribute to the shaping of her body politic (McClennen, p. 30). The conflicting inner/outer "work-out" of exilic consciousness in turn sculpts the search for female identity and positioning in the purgatorial world of patriarchal nothingness that propels her quest journey. "There will always be a place, a country waiting for us, a nada waiting for us... a tender nothingness," Yocandra sighs (p. 3).

In this exilic borderland of waiting for a sense of belonging in Cuba's discursive spaces, Valdés interrogates the incomplete exiled sacrificial women "naked" and "stretched out on the sand, the sea around her, caressing her feverish skin. They have forced her to return to her island, the island that in wanting to build paradise has created hell" (p. 6). Forever caught in la doble moral (double standard) between male/female, inside/outside, on/off, she "doesn't know what to do" (p. 6). "Why swim? Why drown?" she asks (p. 6). I contend that la doble moral is a variation of Batialle's philosophy of liberation in which sexuality becomes both a means and a strategy to write oneself into existence as does the naming and renaming of oneself. Valdés exposes the juxtaposition of these modern binaries, one rational and ordinary and the other experientially destructive and sacred, emphasizing that it within this abject terror of loss, life and death that the initiation to the feminine sacred begins. Employing the sexual act as "as a form of negativity without cause" and eroticism as a pattern of transgressive excess," we witness how women occupy an interstitial space of insilio/exilio as a resistance strategy to challenge the oppressive weight of contemporary Cuba (Rival, Slater, \& Miller, 1999, p. 297).

Within this space, disruptions occur in order to hasten the dissolution of the boundaries of self. In so doing, Valdés discloses how the Cuban Revolution was fueled by aggressive masculinization and militarization, which perpetrated the continued subordination of women within its politico-patriarchal systems. Here, again, we witness how the female body is "the first place that defines political struggles" in which "social flesh" is a "political site of place that mediates the lived experiences of social and cultural relationships" (Harcourt, 2012, p. 292). In these spaces, women's bodies are chessboards where men strategically outplay and outmaneuver each other for the throne of masculine superiority, while women resist the inescapable threat of capture. "The Winner will get to kiss me," Yocandra explains. "What a bunch of idiots!" (Valdés, 1997, p.148). Within these male power plays, Valdés destabilizes the construction of nation, decentering it at its historical foundations thereby shifting the site of nation from the public to the private. Acting as a deterrorializing process, Valdés deftly disrupts localities and opens up spaces for women's bodies to speak.

Examining Patria's sexual patterns, it becomes clear that Valdés's female bodies are the first place that define political struggles in which to observe the complicated intersections of boundaries and power. In this respect, the female body is a metaphor for rape, marginalization and abuse of the Cuban tierra munda. In Yocandra, we witness how "Power relations have an immediate hold upon it; they invest it, mark it, train it, torture it, force it to carry out tasks, to perform ceremonies, to emit signs" (Foucault, 1975 , p. 25). Precisely because women have been banned from the master narrative, women have been forced to deploy their sexual bodies to contest patriarchal revolutionary constructions that have left them outside the narrative.

Without power to rewrite the narrative and enter into the dialogue, during revolutionary movements women "have resorted to subterfuge, digression, disguise, or deathly interruption" (Franco, 1989, p. xxiii). Valdés's sexual transgressions become a way of inserting new discourses into the reshaping of Cuban society. As with many revolutions, including the Sandinista and Zapatista revolutions (both of which I have written about in the past), the Cuban Revolution failed to include a feminist agenda of gender rights and gender justice into its mission. ${ }^{3}$ Women's voices in all three revolutionary movements have been subordinated to the patriarchal prerogatives of the revolution, gender equality and empowerment backburnered for the cause (Randall, 1992, 133). While women acted as "gendered revolutionary bridges," and fought alongside men for liberation, collective feminist consciousness never emerged to become part of the national consciousness (Shayne, 2004, p.154). Thus, the sexual 
encounters of Valdés's female characters suggest a masochist dimension of a subculture attempting to reinvent and to transform itself through the exercise of power. Patria uses her sexuality as a way of entering the dialogue and talking back to Cuba's revolutionary discourses. Debra Castillo (1992) contends that to "speak between the lines" offers a "counterhegemonic response to this official silencing" (p. 41).

This becomes evident in the scene in which La Patria meets The Traitor. Valdés introduces a man who has been made impotent by the revolution, a man who has been castrated and employs his impotence to take advantage of others. At first, he refuses sex with our protagonist because of her name La Patria. After she changes her name to Yocandra, He tells her: "Lose your virginity to someone else" with the inference that he doesn't want to have to feel the guilt and shame of "deflowering" her, a new concoction of La Patria. How can he, an apparatus of Patria, "deflower" La Patria? Wouldn't that be another form of political masturbation? Abiding to the impotent voice of omnipotence, Yocandra chooses a Marochqui, "el macho que la desvirgue," a drunken and drugged corpse of a masculine being whom she meets in an obscure disco bar. Marochqui, already demasculized by revolutionary policies that undermined the livelihood, power, and prowess of the working male, has been staged to receive yet another blow to his manhood-this time by the desirous female construction of the revolution-Yocandra who represents the many women like her who want their voices counted. In this sexual victory, Yocandra's hymen becomes a sexually violent weapon of conquest. "It took some doing," she said, "but finally I managed the beheading" (p. 28). Her hymen served its purpose it had "accomplished its mission: to murder a penis. When the deed was done, my beheaded victim vanished without a trace" (p. 28).

This depiction is one of violent anguish, which Patria experiences emerging as a dialectic at the heart of the impulse to sacrifice and gains it intensity and significance in eroticism. Bataille (1991) puts it thus:

There is no way out and the communication of anguish, which takes place in sacrifice-is not the solution but the introduction, and the maintenance of rupture in the very centre, in the heart of humanity. It is only in the midst of anguish that this being which you are maintains enough consistency and yet leaves gaping the wound through which, hastening from all points of the universe, deadly destruction enters. Without your anguish, you would not be this faithful mirror of excess movements, of the vertiginous flight of the day and night which you have become this is why it would not be for you to refuse that wild amplification of this pain which you are suffering from, of the splendor which follows you, and of your ultimate reality, which sacrifice is. (p. 386)

Patria's transgressive vision suggests how Valdés affirms Bataille's (1988) assertion that "eroticism and sacrifice are both facets of ultimate reality, bringing us into contact with each other in the most raw, and human way" (p. 195). Patria's narration presents the sexual encounter as sexually violent conquest in which she has proven itself as a victor against a debilitated weakened nation. She delivers her blood stained panties as the proof of the conquest of meaningless nothingness. For how can anyone be conquered when he has already been socially and politically emasculated? The Traitor's unwillingness to deflower the country and direct its deflowering and destruction is a war time tactic in which he can now go in and pick up the spoils of war-La Patria herself - an act of betrayal towards woman and nation. The purity of the nation and women are irrelevant. Through the violent play of orgasmic convulsions, La Patria and The Traitor experience the liminality of the sacred. At once immanent and transcendental their erotic sexuality lies beyond the monstrous condition of social stagnation and finitude that plagues humanity affirming Bataille's declaration that "the purpose is to alone oneself in order to become Godlike" (Rival, L., Slater, D., \& Miller, D. 1999, p. 298). In Bataille's manner of materialism, the body, particularly the sexual organs when used for non-reproductive means and extravagant behaviors, is sacred; sacred because it is temptable and mortal. Orgasm as emancipatory experience expands in mysticism as it transcends physical and emotional realms for momentary liberty and freedom. Within this relationship we see Valdés's quest for a new moral order free from compulsion and external imposition. Similar to Bataille, Valdés's sexuality is experienced as a religious sacrifice, through guilt shame and transgression. Religious in nature, it is based on hetereonomic internalization of the sacred, which she locates beyond mortality, rationality and sociality. Valdés subordinates Yocandra's sexual and personal desires only to resurrect her as an intellectual equal. La doble moral is a variation of Bataille's strategy of liberation to confront the inequities of reality. Yocandra questions: "How could I ever love a pervert who could ejaculate only when the head of his penis 
had battered my sex into bloody submission?" (p. 43). As in the nation state, women split, question, and wake up to the physical world around them.

The Traitor's attitude reveals Cuba's failure to lose its patriarchal attitudes towards women, as well as the pervasive machista attitudes of the Revolution's New Man. To support the revolution has always been tantamount to manhood and Che Guevara's essential construction of heterosexism. Valdés has created a Traitor, who although might demand marriage union with Yocandra, possessed a philosophy of nada. "A philosopher? She asks. Living in a virtual pigsty, and without a kitchen or bathroom? A philosopher? Forced to carry buckets of water up to his apartment?" (p. 41). Yocandra reveals the philosophy of the traitor fed on Jacques Derrida, Lenin and Rambo amounts to nothing, but 300 pages filled with the incessant nothingness of daily life in Cuba under Castro. Because he has a sense that everyone in a panoptic Cuba is following him, he finds it hard to write a single word. The Traitor betrays his individual potential and is censored by his own sense of disillusionment. Valdés chastises the philosopher king so absorbed in his head, who can never recognize the reality of his philosophy. When the traitor pushes his way to the front of a ration line for fish, "a fat lady slaps him so hard "across the face she sent him flying into the gutter. He ended up waiting in line for six hours, reading some book by Jaques Derrida" (Valdés , 1997, p. 42).

While Yocandra ultimately divorces the traitor, viewing the sadomasochistic relationship on a performative axis, we see both The Traitor and Patria struggling to take control of time and rhythm by entering, and leaving a space open for the erosion of the illusion of separation and boundaries. We see Valdés placing erotic sexuality outside and in opposition to society in Yocandra's relationship with the dissident Nihilist in which orgasmic pleasure leads to ecstatic surrender and a virtual loss of consciousness. Commenting on her sexual scenarios in her works, Valdés says that that "un es siempre liberación" (an orgasm is always liberation) (Rohter, 1999). Yet, the nihilist has been similarly castrated by the Revolution so that he self-censors himself and refuses to produce and film his screenplay. Like the traitor, he too has been censured devolving into castrated fragments of his former self. The Traitor and the Nihilist represent the Janus-faced psychic fragmentation between the interior and exterior worlds of the 1959 Cuban Revolution and the exiled Cuban caught between the doubled nature of nation and its constant movement between and across the borderlands. In this journey to and fro, Valdés positions her character Patria/Yocandra seized between two commanding male powers that occupy and torment her nocturnal spaces-spaces where sexual, emotional, and psychological brutality reign. In this world, Patria is caught in the anxiety of masculinized sexual power and hysteria aimed at dominating the only thing he can - the seconded and "othered" sex. Through her sexual encounters, Patria contests and confronts the dominant course of identity. Sex becomes a way of breaking the silence to which women have been long subjected and a way to reinsert themselves into both text and nation. Female sexual bodies break open the construction of nation building and expose inconsistencies in present Cuba.

Valdés refuses to let Patria's lovers transcribe their hisstory onto her-story. Her resistance demonstrates her awareness in their complicity in nation building and her steadfast desire to create a historical space of her own. As confirmed by Jean Franco (1989), women are seldom welcomed into the master narrative and so must break down the walls to gain access or create new narratives that are inclusive. Franco writes without the "power to change the story or to enter into dialogue," women "have resorted to subterfuge, digression, disguise, or deathly interruption" (xxiii) Patria's physical-psychic relationships and eroticized orgasms embody the allegorical gendered struggle. Her accumulated climatic struggle offers a way of entering into a society that denies her a space and a voice. Through her sexual interactions, she is provided an alternative way to speak between discourses, which breaks open the imaginary borders of official silencing. Yocandra/Patria becomes an unfixed island capable of moving away from fixed notions of geographical entities. Her sexual exploits within different texts and contexts fortify her own sexual political being in which her personal identity transcends fixity and is fluidly shaped and reconstructed. By resisting all absolute notions and discourses of a specific Cubanness, La Patria gives birth to a new voice of marginalized and disappeared peoples.

Patria reminds us that "She comes from an island that had wanted to build paradise ...." (154). In the end, in confronting her identity, La Patria, Yocandra, Cuba -all acting as one-confronts both what affirms and destroys her:

How beautiful, how utterly beautiful, this harmony of light and color.

I've never seen anything like it. But are they flowers or coffins? 
Is this a garden or a cemetery? I want a garden. I need a garden.

How proud I am to be Cuban! How terrified I am to be Cuban. (Valdés, 1997, p. 153)

\section{FINAL MUSINGS}

A child of the revolution, Zoé Valdés narrates the violence and subjugation of women during Cuba's revolutionary in her novel Yocandra in the Paradise of Nada. Her female characters work to decenter and dislocate revolutionary heterosexist rhetoric that aligns with the ideals of a New Man living under a New Nation. Valdés demonstrates that while, in many instances, Fidel Castro improved lives for women, the Cuban Revolution, in the end, proved nada and decisively patriarchal in the implementation of its political and social rhetoric. Valdés female bodies are testimonies to Cuba's revolutionary period offering an alternative historical record and another vision for Cuba's future.

\section{REFERENCES}

[1] Bataille, G. (1991). The History of Eroticism in The Accursed Share Volumes II \&III, trans. by Robert Hurley. New York, NY: Zone Books.

[2] _. Inner Experience. (1943). Translated by Leslie Anne Boldt. Albany, NY: State University of New York Press. Reprint 1988.

[3] Castillo, D. (1992). Talking Back: Toward a Latin American Feminist Literary Criticism. Ithaca, New York, NY: Cornell UP.

[4] Conboy, K. Medina, N. \& Stanbury, S.(1997). Introduction. Writing on the Body: Female Embodiment and Feminist Theory. New York, NY: Columbia UP. 1-12.

[5] Foucault, M. (1975). Discipline and Punish: the Birth of the Prison, New York, NY: Random House.

[6] Franco, J. (1989). Plotting Women: Gender and Representation in Mexico. New York, NY: Columbia University Press.

[7] Fuentes, Y. (2002). Beyond the Nation: Issues of Identity in the Contemporary Narrative of Cuban Women Writing (in) the Diaspora. Doctoral dissertation. NSU Works.

[8] Grosz, E. (1994). Volatile Bodies: Toward a Corporeal Feminism. Bloomington, IN: Indiana UP, 1994. Print.

[9] Holgado Fernández, I. (2002). ¡No es fácil!! Mujeres cubanas y la crisis revolucionaria. Barcelona, Spain: Icaria Editorial.

[10] Harcourt, W. Women Reclaiming Sustainable Livelihoods: Spaces Lost, Spaces Gained. New York, NY: Palgrave Macmillan, 2012. Print.

[11] McClennen, S.A. (2004). The Dialectics of Exile: Nation, Time, Language, and Space in Hispanic Literatures. West Lafayette, IN: Purdue UP.
[12] Randall, M. (1992). Gathering Rage: The Failure of Twentieth Century Revolutions to Develop a Feminist Agenda. New York, NY: Monthly Review Press.

[13] Rival, L., Slater, D., \& Miller, D. (1999). "Sex and Sociability: Comparative Ethnographies of Sexual Objectification." In Ed. Mike Featherstone's Love and Eroticism. London, England: Sage Publications (295-322).

[14] Rohter, L. (1998, Jan, 7) Arts Abroad; Living With a Shortage of Everything but Desire/ New York Times.

[15] Santí, E. M. (2010). Plante con Zoé Valdés. Bienes del siglo: Sobre cultura cubana.MéxicoCity, México: Fondo de Cultura Económica.

[16] Shayne, J. (2004). The Revolution Question: Feminisms in El Salvador, Chile, and Cuba. New Brunswick, NJ: Rutgers UP.

[17] Valdés Z. (1997). Yocandra in the Paradise of NADA. New York, NY: Arcade Publishing

\footnotetext{
${ }^{1}$ One of the most interesting elements about Everyday Nothingness is this desire to give a political, ideological, historical testimony about this reality that you have lived. There is a need to do not just literature, but to name reality as you see it not as a character, but as yourself.
}

2 In 1993, Valdés wrote the novel, La Nada Cotidiana (The Nothingness of Daily Life), which was smuggled on a raft from Cuba to Miami. A French journalist then took the novel to Paris, and in 1995 Valdés herself moved to France. La Nada Cotidiana, published in Spanish and French, quickly rose to become a best seller in both languages. The novel was later translated into English as Yocandra in the Paradise of Nada. Similar to the author, the young protagonist is born on May 2, 1959 during Cuba's historical revolutionary period when Fidel Castro had risen to power.

${ }^{3}$ See: Toward Enacting a Zapatista feminist agenda somewhere in La Selva Lacondona: We are all Marias?Cogent Arts and Humanities. Vol. 5, Issue 4, 2018. and Women of the Revolution: Gendered Resistance and Agency in the Works of Margaret Randall. Cogent Arts and Humanities. Vol. 4, Issue $1,2018$. 